\title{
Verskillende boodskappe vir verskillende kontekste: Die literatuur van die ballingskap (597-539 vC)
}

E H Scheffler

(Unisa)

\section{ABSTRACT}

Different messages for different contexts: the literature of the exile (597-539 BC)

In this article the biblical literature that originated in the exile is discussed. It is indicated how these different writings (Lamentations, exilic psalms, Jeremiah and his editors, Obadiah, Ezekiel, the Priestly Writer of the Pentateuch and Deutero-Isaiah) addressed specific contingent situations within the broader context of the exile. The variegated messages of these texts in different contexts suggest that the Biblical text should not be regarded as a homogeneous text with one supra-temporal message, but did communicate with people precisely because of its variety and relatedness with specific historical contexts.

\section{INLEIDING}

Hierdie artikel poog om op 'n praktiese wyse 'n bydrae te lewer tot twee aspekte van die resente teologiese debat binne veral die Bybelwetenskappe in Suid-Afrika. Eerstens raak dit eksegetiese metodiek en tweedens die siening van die Bybel as Woord van God.

Wat eksegetiese metode betref het die immanente benaderings soos die struktuuranalise en in 'n mindere mate die literêre benadering die eksegetiese toneel van die afgelope dekades in Suid-Afrika oorheers. Veral die beoefening van struktuuranalise het baie vir die selfbeeld van SuidAfrikaanse eksegete beteken aangesien dit as 'n eie "Suid-Afrikaanse" metode beleef is ${ }^{1}$. Ten spyte van hierdie klem op immanente benaderings, het 'n historiese benadering (hetsy grammaties-histories of histories-krities) steeds (soms op die agtergrond) by sommige eksegete gefunksioneer ${ }^{2}$. Die afgelope paar jaar het daar egter 'n kentering ingetree, en word besef dat immanente benaderings, ten spyte van die relatiewe waarde daarvan, nie die finale woord ten opsigte van teksinterpretasie spreek nie. Klem word weer eens gelê op die waarde van 'n historiese benadering, waarin veral die interpretasie van die betekenis van 'n teks in die konteks van die 
oorspronklike lesers of hoorders van die teks ernstig geneem word. 'n Herwaardering van die historiese kritiek vind plaas, sowel as 'n kennisname van die sogenaamde sosiaal-wetenskaplike metode ${ }^{3}$.

Die status van die Bybel as die Woord van God was ook onlangs onder die loep na die lewering van 'n referaat voor die Ou Testament Werkgemeenskap deur I J J Spangenberg waarin die outeur beweer het dat die Bybel nie as "Woord van God" beskou moet word nie, maar woorde van mense oor God ${ }^{4}$. Hierdie opmerking het 'n ongekende opspraak gewek met ' $n$ hewige debat wat in die pers gevoer is. Moet gelowiges afstand doen van die belydenis dat die Bybel die Woord van God is? My voorlopige antwoord hierop sou wees dat dit nie noodwendig nodig is nie, mits in gedagte gehou word wat met die "Woord van God" bedoel word. Indien die Bybel letterlik as die Woord van God beskou word, beland die belyer van die uitspraak onvermydelik in die vaarwater, aangesien die Bybel uit vele genres bestaan en nie net uit godsprake nie. Vele voorbeelde sou genoem kon word, maar net die versugting van die psalmdigter "Here hoe lank nog?", waar 'n mens in nood kennelik tot God roep, toon duidelik dat 'n mens hier aan die woord is en nie God nie. As mens die woorde van die psalmis letterlik sou opneem as die woord van God, koggel God immers vir God uit. Selfs waar godsprake voorkom, soos byvoorbeeld in Job 3841 , moet in gedagte gehou word dat hierdie godsprake deel is van 'n literêre werk wat deur mense geskryf is. Letterlik kan die Bybel dus nie die Woord van God wees nie, sonder om van die leser daarvan 'n kruisiging van die intellek te verwag nie. Aan hierdie saak kleef daar myns insiens ook 'n etiese dimensie. Indien die kerk sou voortgaan om sodanige kruisiging van lidmate te verwag en laasgenoemde om daardie rede die kerk sou begin verlaat, is hulle verlating van die kerk grotendeels op die kerk se rekening. Myns insiens kan die Bybel slegs as "Woord van God" beskou word indien die uitdrukking dien as 'n metafoor vir die feit dat 'n gelowige in die lees van die Bybel soek na die wil van God vir sy/haar lewe. Die Bybel is die neerslag van 'n soortgelyke soeke van mense van die verlede, en in die lees daarvan gaan die leser in dialoog met soekers van die verledes. Onveranderlike ewige waarhede word nooit finaal gevind nie (mens kyk immers deur 'n spieël in 'n raaisel), selfs al sou mens op 'n bepaalde tydstip so dink. Nederigheid is dus hier van pas, wat immers ook 'n Bybelse deug is. Selfs volgens die Bybel is geloof nie 'n pretensie van sekerheid oor dogmatiese postulate wat ondersteun sou wees deur die "Woord van God" wat konteksloos en apodikties as bewysplase funksioneer nie, maar nederige geloof wat altyd met ongeloof gepaard gaan (Mk $9: 24)^{6}$. 
Myns insiens bestaan daar 'n verband tussen bogenoemde aspekte van die huidige debat, aangesien die beoefening van die immanente metodes (wat ook pretendeer om positiewe "objektiewe" resultate te lewer) maklik aansluiting vind by 'n letterlike siening van die Bybel as die Woord van God. Indien die historiese konteks van 'n teks buite rekening gelaat word kry die teks 'n bowetydelike of "ewige" karakter en is dit vandag netso van toepassing as wat dit twee millennia gelede was. Op hierdie wyse bly die "Woord van God" homogeen en geloofwaardig omdat dit altyd dieselfde beteken in alle situasies.

Hierteenoor hang die interpretasie van die teks binne 'n kontingente historiese konteks (van destyds wat verskil van vandag) weer saam met die siening van die Bybel as Woord van God in die metaforiese sin van die woord, aangesien die soeke na die wil van God vandag in die leesproses impliseer dat die kommunikasie van die teks in sy oorspronklike konteks voorrang geniet. Die konteks van destyds sowel as die konteks vandag kom by die leesproses in die spel en relativeer elke positiewe lees tot so 'n mate dat die leser tot nederigheid gestem word en na die leespoging besef dat hy/sy nie die volle waarheid uit die teks kry nie, maar slegs 'n eie (en minder gevaarlike) blik op die waarheid (maar wat tog ook genade is).

In wat volg gaan gekyk word wat die boodskap(pe) van sekere Bybeltekste in hulle oorspronklike situasies was. Aandag word gegee aan die literatuur van die Judese ballingskap. Die ballingskap was 'n ingrypende historiese gebeure en daar sal aangetoon word hoe die literatuur 'n respons op hierdie gebeure was. Meer nog: dit sal blyk dat daar ook nadere kontekste binne die groter konteks van die ballingskap bestaan het en dat hierdie spesifieke kontekste ook selfs die inhoud van die literatuur (mede)bepaal het. Sake soos lokaliteit (kommunikeer die geskrif in Palestina, Babilonië of Egipte?) en tyd (voor die ballingskap, kort na die ballingskap, halfpad deur die ballingskap of teen die einde van die ballingskap?) kom hier onvermydelik aan die bod. Afgesien van hierdie eksterne kontekste, sal dit ook blyk dat die persoonlikheid of eie disposisie van die outeur(s) ook veranderlikes is wat die boodskap van 'n geskrif bepaal.

Eerstens sal die groter of breër (inter)nasionale konteks kortliks geskets word. Daarna sal die geskrifte telkens indiwidueel bespreek word, waar eerstens aandag gegee sal word aan die spesifieke konteks van die geskrif en dan aan die boodskap van die geskrif binne die konteks. As gevolg van beperkte ruimte sal daar nie hier telkens apart gevra word na die boodskap van die teks (aldan nie) vir vandag nie. Wat hier gebied word poog egter om in die aanbieding daarvan deels die vraag te beantwoord, of minstens ' $n$ raamwerk te bied waarbinne daar sinvol na die hedendaagse betekenis van die teks gevra kan word. 
Verskeie internasionale omstandighede het 'n rol gespeel in die aanloop tot die ballingskap. Toe die Assiriese ryk in die laaste jare van die sewende eeu begin bedreig word deur die Meders en die Babiloniërs, was die einde vir Juda ook in sig. Die stede Assur, Nineve en Haran is onderskeidelik in 614, 612 en 610 verower. Toe die Assiriese koning Assur-uballit in 609 probeer om Haran te herower het Farao Nego II van Egipte hom te hulp gesnel. Koning Josia van Juda het Nego probeer keer by die pas van Megiddo maar self in die slag gesterf. So sterk was Josia se begeerte om van die Assiriese juk ontslae te raak dat hy nie besef het dat hy daardeur in die hande van 'n erger toekomstige verdrukker, die Babiloniërs, speel nie. Juda word nou vir die volgende paar jaar 'n vasalstaat van Egipte met Jehojakim (oudste seun van Josia) as koning.

In 605 vC val kroonprins Nebukadnesar Nego by Karkemis aan en verdryf die Egiptenare. Hy volg sy pa, Nabopolassar, in dieselfde jaar as koning in Babilonië op. Juda kom nou onder die Babiloniese magsfeer. In 601 , na 'n mislukte Babiloniese veldtog teen Egipte, begin Jehojakim, soos ook ander vasalstate, belasting van Babilonië weerhou. Jehojakim sterf in 598 en word deur sy seun Jehojagin opgevolg. Die Judiërs se hoop is nou op Egipte maar Nebukadnesar neem Jerusalem in 597 in en voer Jehojagin en ander leiers en lede van boonste klas van die samelewing (waaronder die profeet Esegiël) na Babilonie weg (ongeveer 3000-5000 mense ${ }^{8}$ ).

Dit sou nog tien jaar duur tot die finale val van Jerusalem. Nebukadnesar stel in 597 Jehojagin se oom Mattanja aan as lakei-regent (Jehojagin in ballingskap was steeds die amptelike koning) oor Juda en verander sy naam na Sedekia. Teen die raad van die profeet Jeremia in, rebelleer Sedekia in 589 teen Nebukanessar wat nou die gefortifiseerde stede van Juda (bv Lagis) inneem en Jerusalem beleër. Die beleëring word in 588 tydelik gestaak wanneer Farao Hofra in 588 'n mag na Jerusalem stuur. Met die hervatting van die beleëring word die stad as 't ware uitgehonger (vgl Klaagl 2:11-12). In 587 breek die Babiloniërs deur die stadsmuur, vang Sedekia en neem hom na Nebukadnesar in Ribla in Sirië. Sy seuns word voor sy oë gedood, sy oë word uitgesteek en hy word na Babilonië geneem. Die tempel, paleis en huise word aan die brand gesteek en die stadsmuur platgeslaan. Sommige belangrike burgers is tereggestel en ander is ook in ballingskap geneem (moontlik 'n verdere 5000).

Die situasie in Juda ná die val van Jerusalem was beroerd. As mens reken dat die bevolking van Juda in hierdie tyd tussen 50000 en 100000 mense was, beteken dit dat ongeveer $10-20 \%$ mense weggevoer is ${ }^{9}$. Die 
meeste het dus agtergebly, maar hulle was die arm mense van die land, terwyl diegene met die vaardighede om die land weer op te bou weg was. Die Edomiete het hulleself in hierdie rampsalige situasie van Juda verlekker en die suidelike deel van Juda, die Negeb, beset. Dit het beteken dat die Judese grondgebied nou ook aansienlik kleiner was en net gestrek het tot ongeveer 30 kilometer ten suide van Jerusalem.

Gedalja, 'n pro-Babiloniese beampte uit Sedekia se regering, word deur die Babiloniërs as goewerneur aangestel met sy administratiewe setel te Mispa. Daar word hy vermoor deur Ismael, 'n lid van die pro-Egiptiese of weerstandsparty wat na Egipte vlug en die profeet Jeremia onder dwang saamneem. In 582 vind 'n verdere wegvoering na Babilonië plaas en Juda word nou deel van die provinsie Samaria. Teen $568 \mathrm{vC}$ is ander state (waaronder Tirus en Egipte) finaal aan Babilonië onderwerp.

Met die verloop van die ballingskap het verskeie konings mekaar in Babilonië opgevolg. Na sy dood word Nebukadnesar in 562 deur Evilmerodag (= Amel-marduk) opgevolg. Hy verbeter die lot van koning Jehojagin wat nou aan sy tafel eet. Evil-merodag word egter in 560 vermoor en deur Nergel-shareser opgevolg. Ook hy en sy opvolger, Lebashi-Marduk word vermoor en Nabonidus word koning gemaak. Sy koningskap sou tot aan die einde van die ballingskap duur.

Die Meders het nou opgang gemaak en Nabonidus voer 'n veldtog teen hulle in Sirië. Hy gaan in bondgenootskap met die Pers Cyrus II (die Bybelse Kores) wat in 559 koning van Persië word. Nabonidus probeer die suide van sy ryk versterk en maak Tema in Noord-Arabië tot sy tweede hoofstad. Tydens sy lang tye van afwesigheid stel hy Belsassar as onderkoning in Babilonië aan.

Nabonidus wou die godsdiens in Babilonië sentraliseer en het die kultus van die maangod Sin erken bo die aanbidding van die hoofgod Marduk. Vir die Jode wat andersins hulleself rustig in kolonies in Babilonië gevestig het, was dit 'n bedreiging want hulle het gevrees dat hulle aanbidding van Jahwe ook bedreig sou word.

In $550 \mathrm{vC}$ het Cyrus die Meders oorwin en koning geword van die groot tweeledige koninkryk van die Meders en die Perse. Persië het nou nie meer 'n bondgenootskap met die Babiloniërs (wat gegrond was op die bedreiging van die Meders) nodig gehad nie. Cyrus maak nou verder opgang deur Lidië (tesame met sy afhanklike Griekse stede) in 546 te onderwerp. Dit het die einde van die Babiloniese Ryk voorspel en die bevryding van die Judese ballinge (vgl Jes 40-55).

Die einde van die ballingskap het spoedig aangebreek. Sonder veel weerstand word Babilonie in 539 vC deur Cyrus verower. Cyrus volg, ter 
wille van eenheid in sy ryk, 'n totaal ander godsdiensbeleid as Nabonidus. Hy herstel die ou godsdiensvorme in Babilonië. Ten opsigte van die Joodse ballinge vaardig hy twee dekrete uit. Volgens die eerste dekreet (vgl Esra 6:3-5) kon die tempel in Jerusalem op Persiese onkoste herbou word onder leiding van Sesbassar wat as prins van Juda aangestel word (Esra 1:8). Volgens die tweede dekreet kon die ballinge terugkeer na Juda onder leiding van Serubbabel, kleinseun of agterkleinseun van Jehojagin.

So goed het sommige ballinge hulleself in Babilonië gevestig dat nie almal van die aanbod gebruik gemaak het nie. Die ballingskap is op verskeie maniere verwerk. Van die ballinge het boere geword of in die bankwese en handel opgegaan. 'n Groot groep het gepoog om hulle Joodse tradisies te bewaar en was in die proses verantwoordelik vir literêre werk van groot omvang wat later deel van die Bybel geword het.

\section{KLAAGLIEDERE}

\subsection{Situasie}

In $597 \mathrm{vC}$ het die Babiloniërs 'n klomp gesiene Israeliete na Babilonië weggevoer. In 586 het hulle die stad met sy tempel, paleis en mure (wat simbolies was van hulle volksbestaan en godsdiens) fisies verwoes en weer 'n groep verban. Net die armstes het in die land oorgebly en Gedalja ('n Babiloniese lakei) is in Mispa (nie eers Jerusalem nie!) deur die Babiloniërs as goewerneur oor hulle aangestel.

In die vyf gedigte ${ }^{10}$ wat die boek Klaagliedere beslaan, vind ons 'n direkte reaksie op die gebeure van 586. Aangesien ons met gedigte te make het wat elk ' $n$ integrale geheel vorm, is dit waarskynlik deur ' $n$ indiwidu of indiwidue geskryf wat die gebeure intens persoonlik beleef het ("Ek sug gedurig, my hart is gebreek", 1:22). Wie die outeur was, is aan ons onbekend. Wat egter wel duidelik blyk (deur onder andere die opname van die boek in die kanon), is dat die digter(s) die lyding wat deur die gemeenskap as geheel ervaar is, verwoord het.

Die gedigte is geskryf in Palestina kort na die verwoesting van die stad en die gedigte reflekteer die sosiale toestande wat toe geheers het:

$\mathrm{Ag}$ hoe verlate is die stad wat vol mense was... (1:1)

Die paaie na Sion treur omdat daar geen feesgangers is nie... (1:4)

Haar hele bevolking sug, hulle soek brood... (1:11)

Buite maai die swaard af en in die huise heers die pes... (1:20).

Die omvattenheid van die lyding wat beleef is, blyk duidelik uit bogenoemde verse. Nie net was die Judeërs gestroop van hulle politieke 
onafhanklikheid nie maar die godsdiens is ontwrig en daar was hongersnood, geweld en siekte. Lyding is ervaar in al sy dimensies: polities, fisies, ekonomies, sosiaal, psigologies en religieus.

\subsection{Die boodskap van Klaagliedere}

Die gedigte van die boek Klaagliedere is in die eerste plek en hoofsaaklik 'n uitdrukking van die diepe leed en worsteling wat die gemeenskap in Jerusalem na 586 beleef het. Die outeur(s) weerspieël 'n bepaalde verwarring rondom die gebeure en beleef dit uiters intens. Die toonaard van die gedigte is dus hoogs emosioneel en nie in die eerste plek 'n poging om die gebeure rasioneel en sinvol te verklaar nie.

Nogtans poog die skrywer(s) om sin te soek in hierdie leed. Die sonde van Israel word genoem as moontlike rede vir die gebeure maar vir die skrywer(s) is die straf nie in verhouding tot die sonde toegedien nie. Daar word gepoog om hoop te vind in die toekoms. Hierdie hoop is egter geen stellige geloof dat daar beslis uitkoms sal wees nie, maar eerder 'n intense smagting daarna (vgl 5:20-22).

Eerder as met 'n duidelike positiewe boodskap, het ons dus in Klaagliedere te doen met die emosionele roue uitdrukking en verwoording van lyding as kontemporêre reaksie op die ondergang van Jerusalem.

\section{DIE EKSILIESE PSALMS}

\subsection{Situasie}

Die gevoelens van ontnugtering oor die politieke onderdrukking en ellende wat met die ballingskap gepaard gegaan het, het soos in die boek Klaagliedere, ook tot uitdrukking gekom in sommige psalms $(=$ liedere, $=$ gedigte) wat in die Psalmboek opgeneem is. Ongeveer agt psalms kon hiervoor in aanmerking (ongeveer 4-5\% van die hele Psalmboek).

Sommige van die eksiliese psalms het 'n indiwidu as outeur wat uitdrukking gee aan sy of haar persoonlike eksistensiële lyding wat die gevolg is van die ballingskap (= individuele klaaglied). Andere kan weer gesamentlike outeurs hê wat uitdrukking gee aan die kollektiewe lyding van die volk as geheel ( $=$ klaaglied van die volk of kollektiewe klaaglied). Dit is ook moontlik dat ' $n$ indiwidu namens die volk of vir die volk 'n kollektiewe klaaglied kon dig wat dan gesamentlik deur hulle gesing is.

In Babilonië was die ballinge sonder die tempel, maar hulle is deur die situasie van onderdrukking waarin hulle verkeer het gedryf om religieuse samekomste te hou. Soms word na hierdie samekomste verwys as "klaagfeeste" waar die ballinge van die psalms gesing het wat aan hulle 
emosies van verlange, leed en ontsteltenis uitdrukking gee. Dit is hoogs waarskynlik dat die meeste van hierdie psalms relatief laat in die ballingskaptyd onstaan het toe die ballinge al reeds geruime tyd oor hulle lot besin het.

\subsection{Die boodskap(pe) van die eksiliese psalms}

Die poësie van die ballingskap is primêr 'n uitdrukking van eksistensiële gevoelens. Nogtans kom daar in hierdie psalms gedagtes na vore wat die "teologiese" perspektief van die outeur(s) weerspieël en wat wel geïnterpreteer kan word as 'n boodskap met die oog op die toekoms. Hierdie "boodskap" is geensins eenduidig nie maar verskil van psalm tot psalm.

Psalm 9-10 vorm één Psalm, het raakpunte met Klaagliedere 3 en is ook akrosties, dit wil sê elke vers begin met die volgende letter van die Hebreeuse alfabet ('n gewilde vorm in die sesde eeu). Die skrywer sien alreeds die ondergang van die Babiloniese ryk, dank Jahwe daarvoor en bemoedig die ballinge (9:13-16). Psalm 51 word volgens sy opskrif gesitueer na Dawid se Batseba-ervaring, maar ons weet nou dat alle opskrifte by die Psalms laat is en nie gebruik kan word om die Psalm te situeer nie. Vanaf vers 20 word ook duidelik gebid vir die herstel van Jerusalem wat 'n ballingskapsituasie veronderstel. Die oorsaak vir die lyding van die volk word (soos meermale gebeur) in persoonlike sonde gesoek en die uitwissing van persoonlike skuld hang dus nou saam met die herstel van Jerusalem. Psalm 60 is waarskynlik 'n Palestynse reaksie kort na die 586 vC. Die volk voel verstoot en verskeur (60:4-5). Hulle bid om God se ingrype en daar bestaan hoop omdat hy aan hulle kant is en die vyand sal oorwin (60:14). In Psalm 74 word God verwyt oor die tempel wat nou reeds lank verwoes en onteer is deur die vyand (74:3-8) en die feit dat Hy niks daaraan doen nie (vgl 74:11). Hy word herinner aan sy koningskap en opgeroep om die armes en onderdruktes te red (74:21-22). In Psalm 77 word die vertwyfeling van die volk omdat Jahwe nie ingryp nie (77:8-11) deur 'n indiwidu bekla. Die digter soek egter na troos deur die God se bevrydingsdade van die verlede te oordink (77:21). In Psalm 102 word die nood van die volk uitgedruk deur die nood van die indiwidu (vgl verse 4-12 met 13-15). Vanaf verse 16-29 word egter (meer as in die vorige Psalms) die vertroue uitgespreek dat God herstel sal bring in die toekoms. Psalm 123 is 'n kort noodroep om hulp te midde van die vernederende omstandighede (spot en veragting deur die vyand) wat die volk nou reeds geruime tyd moes beleef. Psalm 137 se eerste deel (verse 1-4) druk die ballinge se heimwee oor Jerusalem uit, maar kan ná-eksilies wees want dit kyk terugskouend na die ballingskap. Die tweede gedeelte (137:5-9) kom waarskyn- 
lik uit die latere ballingskapstyd en is 'n eksistensiële uitdrukking van wraak teenoor die Edomiete en Babiloniërs.

Alhoewel slegs enkele psalms uit die ballingskapstyd dateer, gee hierdie psalms 'n goeie beeld van die wisselende en uiteenlopende emosies (pyn, moedeloosheid, vertwyfeling, verwyt, wraak, heimweë, troos, vertroue en hoop) wat die ballinge ervaar het na die gebeure van $586 \mathrm{vC}$.

\section{JEREMIA EN SY REDIGEERDERS}

\subsection{Situasie}

Die profeet Jeremia het hoofsaaklik tydens die laaste jare van die Suidryk opgetree waartydens hy die val van Jerusalem voorspel het indien die volk nie geregtigheid toepas en hulle vrywillig aan die Babiloniërs onderwerp nie. $\mathrm{Na}$ die gebeure van 597 en 586 is hy egter nog steeds op die toneel en sit hy sy boodskap in hierdie radikaal veranderde situasie voort. Omdat die geskiedenis laat blyk het dat sy profesieë in die kol was, het dit 'n gesag begin kry onder veral die deuteronomistiese skool (vgl hieronder) wat juis tydens die (voortslepende) ballingskap sin uit die gebeure probeer maak het. Daar moet dus onderskei word tussen die historiese Jeremia se optrede en boodskap, en dié van sy deuteronomistiese redigeerders (voortaan JerD) ${ }^{11}$. Die situasie kort na die wegvoering is veral belangrik vir die verstaan van Jeremia tydens die ballingskap, terwyl die situasie vanaf ongeveer 550-536 belangrik is vir die verstaan van JerD ${ }^{12}$.

Wat Jeremia se situasie in die ballingskap betref, weet ons dat kort na 586, met die dood van koning Sedekia (die vroeëre koning Jojagin wat in 597 weggevoer is, het nog steeds geleef, maar was in Babilon), Israel eintlik leierloos was. Die Babiloniërs het vir Gedalja wat aan die proBabiloniese party behoort het as goewerneur aangestel, maar geweier om hom in Jerusalem te stasioneer, en wel in Mispa ten noorde van Jerusalem. Mens kan jou indink dat hierdie optrede die agtergeblewenes wat nasionalisties gesind was teen die bors gestuit het. 'n Hele aantal het derhalwe besluit om na Egipte te vlug. Hulle dwing Jeremia saam teen sy sin. Daar sit hy sy boodskap in 'n nuwe situasie voort. Dit is onbekend hoe hy aan sy einde gekom het.

Wat die situasie na 550 betref moet in gedagte gehou word dat koning Jojagin nou reeds in ballingskap dood was en dat moedeloosheid onder die agtergeblewenes sowel as die ballinge toegeneem het. Jeremia self was ook nie meer daar nie, maar slegs mondelinge en geskrewe tradisies van sy woorde en dade. In Palestina het die (meesal arm) agtergeblewenes geglo dat herstel eers moontlik kan wees wanneer die leiers uit 
Babilonië terugkeer, daar weer 'n koning sou wees en die tempel met sy tradisionele offerkultus herstel sou word. In Babilonië het die gevaar van sinkretisme (= die vermenging van godsdienste) begin dreig. 'n Aantal ballinge het begin glo dat Jahwe in gebreke bly om hulle te red en het begin wonder of die katastrofe nie toegeskryf moes word aan die straf van die gode omdat hulle deur 'n eksklusiewe Jahwe-aanbidding verwaarloos is nie. Van die opkoms van Cyrus die Pers, en die agteruitgang wat in die Babiloniese ryk geleidelik besig was om in te tree het nóg die gemeenskap in Juda, nóg die in Babilonië van geweet. Die redigeerders van die boek Jeremia (JerD) wat hulle waarskynlik in Palestina bevind het, was derhalwe onder druk om in beide gemeenskappe hoop vir die toekoms te verskaf, maar andersyds valse verwagtinge (polities en religieus) in die kiem te smoor.

\subsection{Die boodskap van Jeremia en JerD}

Wat Jeremia self betref moet in gedagte gehou word dat hy tydens die ballingskap in twee verskillende situsies optree, naamlik in Juda en Egipte ${ }^{13}$. In elke situasie verkondig hy egter steeds die voorwaardelike heil van Juda: hulle sal slegs oorleef indien hulle die basiese vereistes van die deuteronomiese wet nakom, naamlik om Jahwe alleen te dien en sosiale geregtigheid te beoefen. Die herstel van die tempel en kultus of enige koning kan hulle nie red nie. In die praktyk het dit 'n pro-Babiloniese standpunt beteken want Jeremia het geglo dat Nebukadnesar deur God gebruik word om Juda te tugtig. $\mathrm{Na}$ die eerste wegvoering in 597 het koning Sedekia gehoop dat (met die hulp van Egipte) die Babiloniese juk afgegooi kon word. Volgens Jeremia was dit futiel. Na die tweede wegvoering in 586 het Jeremia vir Gedalja (wat 'n lakei van Babilonië was) ondersteun en verkondig dat die enigste heil vir Juda lê in samewerking met Gedalja. Verder skryf hy 'n brief van ondersteuning aan die ballinge in Babilonië: hulle moet hulle daar vestig en met die lewe voortgaan (Jer 29). Nadat hy teen sy sin saam met die vlugtelinge na Egipte is, verkondig hy daar dat Nebukadnesar Egipte sal oorwin en dat die Judeërs ten gronde sal gaan vanweë hulle valse hoop en beoefening van Egiptiese afgodspraktyke (Jer 43-45).

Wat die deuteronomistiese redigeerders van Jeremia betref, kan ons uit die aard van die saak aanneem dat hulle sterk deur die historiese Jeremia beïnvloed is en dit daarom tot hulle taak gemaak het om sy woorde te bewaar en saam met hulle eie toevoegings te boek te stel. Soos die breë deuteronomistiese beweging het hulle ook geglo dat sonde die oorsaak is van die ballingskap. Soos Jeremia self het hulle ook geglo dat hierdie sonde veral bestaan in afgodediens en die gebrek aan sosiale geregtigheid. Hulle 
verskil egter van hulle ander deuteronomistiese kollegas (vgl hieronder) daarin dat hulle nie glo dat herstel in die toekoms van die herstel van die tempel en die sentralisasie van die kultus afhang nie. Die hoop op die toekoms kan ook nie vanuit politieke oord verwag word nie (tydens die ballingskap het baie gehoop op die terugkeer van koning Jojagin en die herstel van die Dawidiese dinastie). JerD verkondig wel 'n hoop wat berus op 'n nuwe verbond waarvan die godsdiens bestaan uit 'n suiwere en eksklusiewe Jahwe-aanbidding en die beoefening van sosiale geregtigheid volgens die voorskrifte van die deuteronomistiese wet. Daarom vereenselwig JerD hulle met Jeremia se woorde by die tempelpoort en lewer dit soos volg oor:

"Vertrou nie op die bedrieglike woorde 'Jahwe se tempel, Jahwe se tempel, die Jahwe tempel is dit!' nie. Maar as julle reg optree, geregtigheid onder mekaar laat geskied, vreemdelinge, wesies en weduwees nie verdruk nie, geen onskuldige bloed in die land vergiet nie en nie agter ander gode aanloop tot julle eie skade nie, dan sal Ek julle laat woon in hierdie land wat Ek vir altyd aan julle voorouers gegee het" (Jer 7:5-7) ${ }^{14}$.

Daar is 'n faset van genade en hoop vir die toekoms wat deurskemer in die klem wat JerD plaas. Daar word nie net beskuldig en nakoming van die wet vereis nie. Alles wat vereis word, sal deur Jahwe self moontlik gemaak word en beide Israel en Juda word betrek:

"Daar kom 'n tyd dat Ek met die huis van Israel (= Israel en Juda) 'n nuwe verbond sal sluit... Ek gee my wet in hulle binneste en skryf dit op hulle hart... Ek sal hulle God wees en hulle my volk... Ek sal hulle ongeregtigheid vergewe en aan hulle sonde nie meer dink nie..." (Jer 31:31-34).

As gevolg van die werk van JerD bevat die boek Jeremia as geheel dus 'n drieledige boodskap: oordeel oor Juda, oordeel oor die nasies en bevryding vir Israel as geheel. Die idee van die nuwe verbond het uiteraard in die konteks van ballingskap in die eerste plek Israel en Juda in die oog. Dit verbaas egter glad nie dat (as gevolg van die klanke van genade) hierdie teks baie kosbaar was vir die vroeë Christene nie (Nuwe Testament = nuwe verbond, vgl Heb 8:8-12). 


\subsection{Situasie}

Die profeet Obadja is na alle waarskynlikheid (anders as Jeremia) 'n kultusprofeet met nasionalistiese sentimente wat die val van Jerusalem in $586 \mathrm{vC}$ beleef het. Hy is egter nie soos Esegiël na Babilonië of Jeremia na Egipte nie, maar het in Jerusalem agtergebly. Die oorsprong van sy geskrif was dus in Palestina. In die geskrif wat sy naam dra, reageer hy nie in die eerste plek op die ballingskap as geheel nie, maar rig hom tot 'n spesifieke situasie, te wete die samewerking wat die Edomiete aan die Babiloniërs gegee het tydens hulle inval. Uit die boek kan ons aflei dat die Edomiete wat oorkant die Jordaan in die suide gewoon het (in die omgewing van die huidige Petra, vgl vers 3 ) hulle in die ondergang van Jerusalem verlekker het en ook saam met die Babiloniërs aan strooptogte deelgeneem het ${ }^{15}$.

\subsection{Die boodskap van Obadja}

Obadja poog om die moedelose Judiërs wat agter gebly het en die vernedering deur die Edomiete moes verduur, te troos. Sy boodskap in hierdie situasie bestaan daaruit dat hy 'n skerp oordeel oor die Edomiete uitspreek vir wat hulle gedoen het. God sal hulle dade van broederlike (via Esau is hulle aan Israel verwant) verraad wat bestaan het uit verlekkering in Juda se lyding, moord op vlugtelinge en plundering van Judese besittings saam met die Babiloniërs, beslis straf. Hul voordelige geografiese posisie (bewoning van rotsklowe en berge) sal die Edomiete dan nie help nie. Alhoewel Obadja aanvanklik reageer op 'n spesifieke gebeure rakende die Edomiete, kring sy boodskap wyer uit en kondig hy die dag van Jahwe aan wat die nasies sal tref maar die herstel van Juda en die eertydse Israel sal beteken. Hulle grondgebied sal op die ou end groter wees as voorheen. As nasionalis identifiseer hy hom volledig met sy volk en gee nie (soos bv die profeet Jeremia) vir die volk self die skuld vir hulle eie ondergang nie. Gedrenk in die Sionsteologie, stel hy ook nie (soos bv Jeremia en die Deuteronomis) voorwaardes vir die politieke herstel nie.

\section{DIE DEUTERONOMISTIESE GESKIEDSWERK}

\subsection{Situasie}

Die Deuteronomistiese Geskiedswerk (ook na verwys as die Deuteronomis of D) omvat die boeke vanaf Deuteronomium tot 2 Konings (uitgesonderd Rut). Soos Klaagliedere, Obadja en die vroeëre periode van Jeremia ver- 
teenwoordig dit ook 'n reaksie op die ballingskap vanuit Palestina. Die werk is waarskynlik tussen 561 en 520 voltooi aangesien dit bewus is van Jojagin se goeie behandeling ( 2 Kon 25:27) in Babilonië maar nie weet van die opkoms van die Pers, Cyrus, nie (vgl die historiese oorsig hierbo en die paragraaf oor Deutero-jesaja hieronder).

Die Deuteronomis is 'n sistematiese beskrywing van die hele geskiedenis van Israel vanaf die tyd van Moses (Deuteronomium) tot en met die begin van die ballingskap ( 2 Kon 25 ). Waar die boek Klaagliedere en sommige psalms 'n roue eerste reaksie van 'n agtergeblewe indiwidu of indiwidue is kort na die wegvoering van $586 \mathrm{vC}$, het daar nou reeds ongeveer vyf-en-twintig jaar verloop. Soos Klaagliedere getuig D ook daarvan dat dit ' $n$ ingrypende verwoesting was wat baie pyn tot gevolg gehad het:

Die Galdeërs het die bronspilare, die waentjies en die bronswaterbak wat by die huis van die Here was, stukkend gebreek en die brons na Babel toe gevat (2 Kon 25:13).

In die tyd wat verloop het, het die "teoloë" van die deuteronomistiese skool oor die ballingskapsgebeure gereflekteer en 'n antwoord probeer gee oor waarom die katastrofe hoegenaamd plaasgevind het. Hulle vind hulle antwoord in die geskiedenis en vertel dan die geskiedenis van Israel (die Noord- en Suidryk) vanuit hulle teologiese perspektief. Hulle redigeer 'n vroeër werk van hulle wat ongeveer $600 \mathrm{vC}$ geskryf is en uit verskeie ou tradisies bestaan. Die Deuteronomis spreek mense aan wat al moedeloos geword het omdat die ballingskap so lank duur. In Babilonië moes die ballinge aanskou hoe die Babiloniese gode in die openbaar vereer is (Jes 46:1-7) en hoe die Babiloniërs die wêreld oorheers het. Daarteenoor het Jahwe, die God van Israel, magteloos voorgekom ${ }^{16}$.

\subsection{Die boodskap van die Deuteronomis}

Uit die boek Deuteronomium kan mens sien dat gehoorsaamheid aan die wet van Moses vir die Deuteronomis 'n voorwaarde was vir heil. Die aanbidding by slegs een heiligdom (Deut 12) en die betoning van barmhartigheid (Deut 15:4-11) was belangrik. Die aanbidding van vreemde gode (Deut 5:6-10), waarsêery (Deut 18:10,14), kinderoffers (Deut 12:31; 18:10), kultiese prostitusie ( 1 Kon $14: 24 ; 15: 12 ; 22: 47$ ) en gemengde huwelike (Deut 7:2-5) moes vermy word. Hierdie wet is telkens oortree (bv Agab met Nabot se wingerd) en dit was volgens die Deuteronomis die rede vir die val van die Noordryk in 721. Die Suidryk het nou ook geval as 
gevolg van die sondes van die konings (veral Manasse). Selfs Josia se hervormings kon die val nie keer nie, maar het dit slegs vertraag.

Die Deuteronomis vertel en vertolk dus die geskiedenis sodat die hoorders van sy dag 'n les daaruit moet leer. Al hoop wat hulle vir die toekoms kan hê moet gebou wees op berou en bekering, die nakoming van die wet en die dien van Jahwe alleen. Hulle moet ook bou op die goeie van die geskiedenis, naamlik die tempel, die Dawidiese monargie en die tye van bekering, genade en verlossing (Rig 2:10-16; 10:6-16; 1 Sam 7:3-11; 2 Kon 13:4; 14:25-27; 18-20; 22-23). God is steeds genadig (Deut 4:31) en magtig (Rig 6; 1 Kon 18) en daar sal herstel wees as die sentrale staatskultus in Jerusalem herstel word en die wet van God in mense se harte geskryf is (Deut 30:6; vgl ook Jer 31:33).

\section{DIE BOEK ESEGIëL}

\subsection{Situasie}

Die boek Esegiël kan grotendeels (latere redaksies in ag genome) beskou word as die neerslag van die profesieë van die groot ballingskapsprofeet Esegiël wat vanaf 597 vC en vir 'n groot deel van die ballingskap na 586 $\mathrm{vC}$ in Babilonië opgetree het. In hierdie tyd het baie dinge gebeur, met die gevolg dat ons ook ten opsigte van Esegiël met wisselende situasies te make het. In 597 het 'n eerste wegvoering van mense uit die boonste laag van die samelewing van Palestina na Babilonië plaasgevind. Dit het koning Jojagin en onder andere 'n groep Sadokitiese priesters, waaronder Esegiël getel het, ingesluit. Esegiël bevind hom dus vroeg reeds in Babilonië: "op die vyfde van die maand in die vyfde jaar van Jojagin se ballingskap" ( $\mathrm{d}$ w s 5 Mei 592) ontvang hy sy eerste visioen by die Kebarrivier (Eseg 1:1-3).

In die tydperk vanaf 597 tot die finale val van Jerusalem het die mense in Palestina nog steeds op die bevryding van Jerusalem gehoop. $\mathrm{Na}$ die val in 586 word 'n verdere groep na Jerusalem gedeporteer wat heel moontlik ook hoë figure was en wat in Babilonië in kontak met Esegiël gekom het en op 'n vroeë terugkeer gehoop het. Dit vind egter nie plaas nie en na vyftien jaar (ongeveer 571) tree daar 'n algehele moedeloosheid onder die ballinge in. Esegiël het 'n boodskap vir elkeen van hierdie situasies en dit word in die inhoud van sy boek weerspieël17.

\subsection{Die boodskap van Esegiël}

Die boek Esegiël illustreer by uitnemendheid hoe 'n boodskap direk verband hou en selfs deur 'n situasie medebepaal word. Hy tree oor 'n lang tydperk op en in hierdie tyd bly sy boodskap nie dieselfde nie maar wissel na gelang van die situasie. 
In die tydperk van die eerste wegvoering (597-586) was Esegiël uit en uit 'n doemprofeet. Hy bevind hom in Babilonië maar het 'n skerp boodskap vir sy mense tuis: hulle hoop tevergeefs dat Jerusalem die aanslag van die Babiloniërs sal vryspring. Dit is deel van God se plan dat Jerusalem vernietig sal word. Dit sal gebeur as straf op die sonde van die volk wat nie primêr (soos vir Jeremia) bestaan het in die oortreding van morele en etiese voorskrifte nie, maar die verkeerde beofening van die kultus. Esegiël was immers 'n priester.

$\mathrm{Na}$ die val in 586 raak Esegiël 'n bietjie meer simpatiekgesind teenoor sy mede-ballinge. Sy vrou is in hierdie tyd dood en dit kon dalk 'n temperende invloed op hom gehad het. Indien die ballinge die val van Jerusalem as deel van God se plan aanvaar, kwalifiseer hulle weer vir heil. Die heil verskuif nou egter na die vlak van die indiwidu: elkeen moet sigself ondersoek en rein voor God lewe. God berei egter die wêreldtoneel voor vir Israel se bevryding: daarom kondig Esegiël nou die die oordeel oor die nasies, Ammon, Moab, Edom, Filistea, Sirië en Egipte, aan (Eseg 25-32).

Teen ongeveer 571, toe groot moedeloosheid onder die ballinge intree, verkondig Esegiël baie meer openlik heil vir Israel. Hy is die wagter (33:1-20), Jahwe is Israel se herder (34:1-31), die terugkeer is soos 'n opstanding van die vlees (37:1-14), die Noord- en Suidryk sal verenig $(37: 15-28)$ en met die versameling van Israel sal die gees uitgestort word (39:23-29).

Soos die tyd vorder, moontlik kort voor die afloop van die ballingskap, word Esegiël nog meer konkreet in sy verkondiging van heil vir een verenigde Israel. Hy verskaf nou 'n bloudruk vir die toekoms ${ }^{18}$ wat 'n nuwe visie bied op 'n nuwe tempel, 'n nuwe kultus en 'n nuwe land.

Die nuwe tempel sal die middelpunt van die land vorm, los van die staat (wat in die verlede verbrou het) staan en deur God self bewoon word tot voordeel van die volk $(40: 1-43: 12 ; 45: 1-8)$.

In die nuwe kultus sal reinheid deur allerhande voorskrifte gewaarborg word (vgl ook die Priestergeskrif wat soos Esegiël ook 'n priester was). Om die afgodediens van die verlede te vermy moet die kultus los van die staat wees. Die priesters moet deur eie landboupraktyke vir hulle self sorg (Eseg 45:1-8; 48:8-14). Die Sadokitiese priesters (Esegiël se groep) sal die belangrikste wees en die kultus en volkslewe beheer deur middel van die offers, onderrig en regspraak. Die Leviete sal hulle bystaan met minder-waardige take soos die slag van die offerdiere en die bewaking van die poorte.

Die herstel wat Esegiël in die vooruitsig gestel het, het egter die land as geheel geraak. Alles (ook die profane) is vanuit 'n godsdienstige pers- 
pektief gesien. In die nuwe Israel word die ou stamgrense geïgnoreer en konsentries om Juda en Benjamin hertrek sodat Jerusalem en die tempel in die middelpunt kan wees. Die bedoeling daarvan was eerstens om die tempel en godsdiens sentraal te stel en tweedens om die land regverdiglik te herverdeel19.

By Esegiël sien ons dus 'n ontwikkeling in sy boodskap soos wat die ballingskap vorder, van 'n doemprofeet tot 'n "teoloog van bevryding". Hy illustreer dus by uitnemendheid hoe kontingent 'n boodskap kan wees en hoe sterk bepaal deur die tyd en situasie, en selfs deur die persoonlikheid en persoonlike omstandighede van die boodskapper.

\section{DIE PRIESTERGESKRIF (P)}

\subsection{Situasie}

Die Priestergeskrif (geskryf deur een of meer priesters, voortaan P) vorm die grootste deel van die Pentateug20. Dit bestaan hoofsaaklik uit ou vertellings, wette en kultiese voorskrifte. Daar bestaan ook 'n noue verband tussen Esegiël en P, alhoewel P waarskynlik later is. Die opskrifstelling van $P$ vind na alle waarskynlikheid teen die einde van die ballingskap plaas en word in die periode na die ballingskap as deel van die Pentateug afgerond.

$\mathrm{Na}$ ongeveer veertig jaar in ballingskap sien $\mathrm{P}$ die gevaar dat die ballinge besig is om hulle identiteit te verloor. Hulle is nou al meer as 'n geslag reeds sonder die tempel en die sentrale aanbidding in Jerusalem wat hulle as volk gekenmerk het en bymekaar gehou het. Op ekonomiese gebied was die ballinge ook geredelik voorspoedig. Hulle is aan die Babiloniese godsdiens blootgestel en die gevaar was daar dat hulle dit ook sou beoefen. So was daar byvoorbeeld die Babiloniese skeppingsverhaal wat vertel het van die skepping van die hemel en aarde in sewe dae. Die Priester vertel nou ook 'n skeppingsverhaal en plaas dit aan die begin van die Pentateug. Hy neem die sewe-dag skema van die Babiloniese verhaal oor, maar beklemtoon dat God die skepper is. Pritchard ${ }^{21}$ gee die volgende vergelyking tussen $P$ en die Babiloniese verhaal wat 'n besondere insig gee in $\mathbf{P}$ se werkswyse in sy konfrontasie met Babiloniese tradisies:

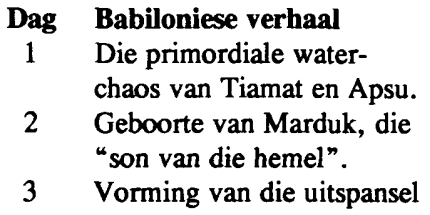

\section{Genesis 1}

Die aarde woes en leeg, die donker wêreldvloed. Skepping van lig

Skepping van die uitspansel. 

uit Tiamat se liggaam.
4 Uitmeet van Apsu se deel,
Versameling van waters om die aarde.
5 Die opstel van die sterrebeelde.
$6 \quad$ Skepping van die mens om die gode te dien.
7 Die gode se onthaal.
die aarde te vorm.
Die skepping van ligte in die uitspansel.
Skepping van die mens om oor die aarde te heers.
God rus op die sabbatdag.

\subsection{Die boodskap van $P$}

Soos Esegiël beywer $\mathbf{P}$ hom vir die heropbou en hervorming van die gemeenskap in die ná-eksiliese tyd. Dit moet geskied deur 'n goed georganiseerde kultus en die nakoming van wetsvoorskrifte wat veral deur priesters bemiddel word (vgl Num 2). Al hierdie voorskrifte word ingebed in die vroeë geskiedenis (skepping, sondvloed, Abraham en veral Sinai) met die doel om gesag daaraan te verleen. Volgens $P$ het hierdie wette toe al gegeld, en daarom is dit ewige wette wat vir sy dag ook geld. Soos vir die Deuteronomis is die tempel wel sentraal, maar God is nie gebonde aan die tempel nie. Daarom is die teenhanger van die tempel in $\mathrm{P}$ die tabernakel in die woestyntyd, waarin God nie woon nie, maar soms in 'n wolk met sy heerlikheid (כבד) verskyn. Die mens ontmoet God nie direk in die tempel nie, maar deur die rituele en soenoffers soos bemiddel deur die priesters (vgl die rol van Noag na die sondvloed, Moses en Aäron van ouds).

Vir $\mathbf{P}$ is veral vier ou tradisies belangrik wat die basis verskaf vir hedendaagse voorskrifte. Hierdie ou tradisies kan mens interpreteer as fases in God se openbaring. $P$ begin sy verhaal dus met 'n skeppingsverhaal (Gen 1:1-2:4a) en propageer daardeur die onderwerping van die wêreld, dieëtvoorskrifte met die onderhouding van die sabat as teken. Tweedens volg die sondvloed met voorskrifte aan Noag en die reënboog as teken (Gen 9:1-17). Derdens volg die verbond met Abraham met die besnydenis as teken (Gen 17). Die Sinaï-gebeure is sekerlik die belangrikste vir $\mathbf{P}$, aangesien sy hele visie vir die kultus daaraan gekoppel word (Eks 19; 24-25; 34-35).

Hoe troos P nou die ballinge met sy werkswyse? Deurdat hy die ou verhale vertel herinner hy die ballinge daaraan dat daar vroeër in die geskiedenis ook chaotiese situasies (choas voor skepping, sondvloed, vreemde land, woestyn) was wat deur God beredder is. God kan dit dus nou weer doen.

Deurdat $\mathbf{P}$ aan die ou tradisies bepaalde voorskrifte koppel, beklemtoon hy dat die nakoming van hierdie voorskrifte uiters belangrik in die toekomstige bestaan van die samelewing sal wees. Soos in die woestyn, is 
God nie aan 'n plek of die tempel gebonde nie, maar Hy kan beleef word (nou in die ballingskap en in die toekoms) in die kultus, die besnydenis, die sabat en die bestudering en nakoming van die wet. Hierdie siening van $P$ het die ontstaan van sinagoges moontlik reeds in die ballingskap moontlik gemaak. Laasgenoemde was verskeie plekke van samekoms waar die wet bestudeer is en die sabat onderhou is.

Opsommend kan dus gesê word dat die Priester met sy geskrif hoop vir die ballinge wil gee en uiteensit waaruit die godsdiens van die toekoms sal bestaan.

\section{DEUTERO-JESAJA}

\subsection{Situasie}

In hoofstuk 40-55 van die boek Jesaja het ons (op grond van styl, taal, situasie en boodskap) duidelik met 'n ander profeet as Jesaja van Jerusalem (Jes 1-39) te doen ${ }^{22}$. Die naam van hierdie tweede ballingskapsprofeet ken ons nie en hy word derhalwe Deutero-Jesaja (= Tweede Jesaja) genoem. Sy optrede val ongeveer in die laaste agt jaar van die ballingskap (546-539 vC). Nebukadnesar is reeds in 562 dood en is binne sewe jaar deur drie konings opgevolg ( $\mathrm{vgl} \mathrm{hierbo).} \mathrm{Toe} \mathrm{Nabonidus} \mathrm{in} 556$ aan bewind kom en die aanbidding van Marduk vervang met die van die maangod Sin, versleg sake en hy moet vlug. Intussen het die kroonprins, Belsassar die administrasie oorgeneem. Veranderinge op internasionale terrein het ook begin intree met die opkoms van Cyrus (= Kores) die Pers. Cyrus het reeds in 546 vC Croesus, die koning van Lydië verslaan, asook Egipte, en die Babiloniese ryk begin bedreig. In $539 \mathrm{vC}$ het hy hom as die bevryder van diegene wat die Marduk-aanbidding aanhang voorgehou en Babilon sonder slag of stoot ingeneem.

Die profeet Deutero-Jesaja was deeglik bewus van die opkoms van Cyrus en laasgenoemde speel 'n belangrike rol in sy profesieë $(41: 2-3,25)$. Alhoewel Jerusalem ook in sy profesieë aangespreek word, bevind Deutero-Jesaja homself tussen die ballinge in Babilonië. Hy was nie deel van die priesterlike beweging soos Esegiël en $\mathrm{P}$ nie, maar 'n profeet wat hom die lyding van die ballinge sterk aangetrek het. Hierdie lyding van die ballinge het hy raakgesien op vele lewensterreine. Dit het nie net gegaan oor die verlies van die land nie, maar ook die fisiese, psigologiese, geregtelike en sosiale lyding wat die ballinge beleef het ${ }^{23}$. Die ballingskap was nou reeds lank aan die gang en (alhoewel dit op ekonomiese terrein nie te sleg gegaan het nie) het die ballinge begin hoop verloor en moedeloos geword. Dit was met ander woorde moeilik vir die ballinge (en die wat in 
Jerusalem agtergebly het) om die sin in te sien van alles wat gebeur het. Die gevaar het ook bestaan dat hulle die Babiloniese godsdiens sou begin aanneem.

Deutero-Jesaja was egter 'n profeet in 'n heel unieke sin. Alhoewel hy die algemene profetiese siening gedeel het dat die ballingskap die gevolg was van Israel se sonde, het hy nie soseer daarop klem gelê nie, maar wou hy eerder die ballinge in hulle situasie troos en sin gee aan hulle lyding. Hoofstukke 40-48 handel oor die profeet se vroeëre optrede en gaan veral oor die opkoms van Cyrus. Hoofstukke $49-55$ bevat die sogenaamde "troosboek" en reflekteer sy latere optrede kort voor die einde van die ballingskap ${ }^{24}$.

\subsection{Die boodskap van Jesaja van die ballingskap}

Deutero-Jesaja probeer die ballinge en die agtergeblewenes in Jerusalem se lyding aanspreek deur hulle te troos en die terugkeer van die ballinge aan te kondig wat die Here deur sy kneg Cyrus sal bewerkstellig (45:1-5). In die proses wil hy ook sin gee aan hulle lyding deur hulle aan te spoor om hulle wêreldbeskouing te verander. Volgens hom moet die Israeliete anders dink oor God, hulleself en die nasies ${ }^{25}$.

(1) Wat God betref herinner die profeet die mense aan verlossingsdade van die verlede soos die eksodus. Soos toe, sal God ook nou verlos. Israel se lyding kry egter perspektief wanneer dit in terme van die skepping as geheel gesien word. God is in beheer van die skepping en daarom kan hy Israel verlos as deel van sy skeppingswerk. Verder word die ballinge tot monoteïsme opgeroep. Dit beteken dat Jahwe die enigste God is en dat afgode (hetsy van die Israeliete self of die Babiloniërs) geen mag het nie. Slegs die enigste Skeppergod kan die ballinge bevry. Dit doen Hy nie deur priesterlike voorskrifte en wette nie (anders as Esegiël en P), maar vrylik op grond van sy genade, liefde en barmhartigheid (vgl veral 54:1-10).

(2) Wat hulleself betref moet die Israeliete besef dat hulle instrumente in die hand van God is waardeur Hy lyding in hierdie wêreld verlig. As God 'n mens soos Cyrus kan gebruik wat Hom nie ken nie, hoeveel nie te meer Israel wat Hom ken nie. Soos die profeet, wat deur sy profesieë reeds as kneg van God optree om hulle lyding te verlig, moet al die Israeliete self ook knegte van Jahwe word. Deurdat hulle ander help, help hulle ook hulleself. Hierdie gedagte kom veral voor in die knegliedere 26 wat ' $n$ integrale deel van Deutero-Jesaja se boodskap vorm. Daar is progressie in die liedere wat die kneg se eie lyding betref en dit bereik sy hoogtepunt in die vierde lied (52:13-53:12): die lyding van die kneg as sodanig bewerk verlossing. Indien mense wat ly hulle eie lyding só sien, verkry die lyding sin en word die lyding draagliker ${ }^{27}$. 
(3) Die Israeliete moet ook hulle tradisionele siening van die nasies (= heidene) verander. Die tradisionele Sionsteologie wat in swang was voor die ballingskap was té nasionalisties en was deels ook die oorsaak van die ballingskap. Die universalisme wat die profeet nou voorhou beteken dat Israel moet besef dat God die heil van al die nasies op die oog het. Omdat dit gegrond is in God se barmhartigheid en genade, kan dit nie anders as om alle mense (en die skepping as sodanig) in te sluit nie (55:1-13).

Die profeet verkondig dus troos aan Israel, en wil juis daarom in die proses die lydendes se aandag fokus weg van hulle eie lyding na die wyse waarop hulle instrumente in die opheffing van ander se lyding kan word. Dan kry hulle lyding sin en kan hulle die gebeure van die ballingskap verwerk.

\section{GEVOLGTREKKING}

Uit bogeneomde bespreking van die ballingskapsliteratuur kan ons aflei dat die krisis en ontwrigting wat die ballingskap veroorsaak het as 't ware die kruitvat was wat 'n uitgebreide literêre aktiwiteit tot gevolg gehad het waarvan die produk op die ou end 'n wesenlike deel van die Hebreeuse kanon sou uitmaak. Die pyn van die ballingskap het verskeie mense (digters, priesters, geskiedskrywers, kultusprofete en indiwiduele profete) na die pen laat gryp in 'n poging om die gebeure te verwerk. Hierdie mense het geskryf in verskillende situasies: die outeur(s) van Klaagliedere en sommige psalmdigters, die Deuteronomis, Obadja en Jeremia was in Juda, Esegiël, die Priesterskrywer(s), Deutero-Jesaja en ander psalmdigters was in Babilonië en Jeremia was later selfs in Egipte. Na aanleiding van hulle eie oortuigings en spesifieke situasies tydens die ballingskap wissel die boeke se boodskap. Klaagliedere en sommige psalms bevat 'n eerste intense uitdrukking van die smart wat die val van Jerusalem te weeg gebring het. Jeremia verkondig dat die heil van Israel eintlik by die Babiloniërs lê en JerD verkondig dat God in die toekoms 'n nuwe (etiese) verbond met Israel sal sluit. Obadja spreek die spesifieke gebeure rondom Edom se verraad aan en verkondig 'n toekomstige herstel van Juda aan wat imperialistiese trekke vertoon. Later probeer die Deuteronomiste die ballingskap aan die sonde van Israel (veral die konings) toeskryf. Die Priesterskrywer(s) lê klem op ou tradisies en die wet van God wat basies moes kompenseer vir die afwesigheid van die land en tempel. $\mathrm{Na}$ 'n aanvanklike verdoeming van die Judiërs, verkondig Esegiël teen die einde van die ballingskap die programmatiese herstel van Israel as geheel. Deutero-Jesaja toon baie empatie met Israel se lyding, maar verkondig dat 
die betekenis daarvan daarin lê dat Israel deur sy lyding 'n instrument word waaruit alle nasies voordeel sal trek.

Uit die ballingskap en die literatuur wat daaruit ontstaan het kan ons dus duidelik sien hoe verskillende Bybelse tekste verskillende boodskappe bevat wat deur verskillende situasies bepaal word. Die tekste wat in die Bybel vervat is, is nie dogmas wat bo die tyd swewe nie maar het juis betekenis vir mense gehad omdat dit gekommunikeer het in konkreet menslike situasies.

\section{NOTAS:}

1 Vergelyk A B du Toit, "Strukturele teksanalise en die Suid-Afrikaanse redevoeringsanalise", Skrif en Kerk 2 (1981), 3-14.

2 Die verhaal van die twee benaderings (en ander) die afgelope dekades is wat die Ou Testament betref meesterlik vertel deur $\mathrm{J} \mathrm{H}$ le Roux in sy The story of two ways, Pretoria 1993. Vergelyk ook J H le Roux, "Eksegese is 'n spel”, Acta Theologica 2 (1996), 41-56.

3 A B du Toit en andere se boek The New Testament milieu, Halfway House 1998, is veral hier van besondere betekenis. Hier word nie bloot Zeitgeschichte aangebied nie, maar pertinent gereflekteer oor "historiese konteks" in al sy betekenisse en aangetoon hoe die konteks bepalend is in die eksegetiese proses. Veral Du Toit se uitleg van die Gelykenis van die barmhartige Samaritaan (Luk 10:30-37) is hier van belang, en veral sy opmerking: “This parable is a good example of a New Testament passage whose real point would be lost without background knowledge". Vir 'n uitleg van genoemde gelykenis waarin aan beide die immanente en historiese aspekte aandag gegee word, vergelyk $\mathrm{E} \mathrm{H}$ Scheffler, "Die barmhartige Samaritaan", in: F Swanepoel (red), Bybelse stories en hulle geheim, Pretoria 1989, 58-69. Oor die voortgaande waarde van die historiese kritiek, vergelyk J H le Roux, "Historical criticism - the end of the road?", OTE 7/4 (1994), 198-202.

4 In sy referaat "Die Ned Geref Kerk, die boek Jona en religieuse pluralisme" (gelewer by die Ou Testamentiese Werkgemeenskap in Stellenbosch, September 1996) wys Spangenberg op paradigmaveranderinge en die invloed daarvan op verskillende Skrifbeskouings.

5 Deist verwys na die Bybel as "'n bron van vloeibare geloofsgeskiedenis" waarin "meer as ' $n$ duisend jaar se lewe saam met God" verwoord is. Vergelyk F Deist, Wat van vandag?, Kaapstad 1986, 7.

6 Vergelyk my meditasie "Geloof as nederigheid" in: E H Scheffler, Die konsekwensies van geloof, Pretoria 1996, 6-9.

7 'n Magdom geskiedenisse van ou Israel bevat inligting oor die ballingskap. Behalwe vir die toepaslike Bybeltekse (bv 2 Kon 25) het ek in die onderhawige konstruksie veral gebruik gemaak van J H le Roux, "Theology in a crisis", in: F E Deist \& J H le Roux, Revolution and reinterpretation: chapters from the history of Israel, Pretoria 1987, 109-124; H C van Schalkwyk, 'n Volk in krisis: 'n holistiese benadering tot die Judese ballingskap (MA-Verhandeling, Unisa), Pretoria 1996, 13-69; F F Bruce, Israel and the nations, Exeter 1963; J M 
Miller \& J H Hayes, A history of ancient Israel and Judah, Philadelphia 1986, 416-436; M Noth, Geschichte Israels, Göttingen 1950, 253-270; S Herrmann, Geschichte Israels in alttestamentlicher Zeit, München 21980, 335-362; H Jagersma, Geschiedenis van Israel in het oudtestamentische tijdvak, Kampen 21984, 243-268; P R Ackroyd, Exile and restoration: a study of Hebrew thought of the sixth century BC, London 1968, 1-38; G Fohrer, Geschichte Israels: von den Anfängen bis zur Gegenwart, Heidelberg 21979, 185-195 en N P Lemche, Ancient Israel: a new history of Israelite society, Sheffield 1988, 173-185.

$8 \quad$ Vir 'n bespreking van die aantal weggevoerdes, vergelyk Lemche, $a w, 175-$ 176.

9 Vergelyk Lemche, $a w, 175-176$.

10 Die inhoud van die vyf klaagliedere kan as volg getipeer word: 1 : die lyding van Jerusalem; 2: die toorn van die Jahwe; 3: hoop ten spyte van die diepste nood; 4: die verskrikking van die beleëring; 5 : smagting na herstel.

11 Die historiese Jeremia het nie alleen oor ' $n$ lang tydperk opgetree nie, maar die boek wat sy naam dra het opsigself ' $n$ lang ontstaansgeskiedenis gehad (vgl bv Barug se aandeel in die teboekstelling, Jer 36). Soos met die geval van die evangelies in die Nuwe Testament, begin die ontstaansgeskiedenis wel met die optekening van die woorde van die historiese Jeremia, maar sy redigeerders verander en voeg by in die naam van Jeremia. Waarskynlik is die boek in sy eerste fase tydens die ballingskap (of kort daarna) deur die Deuteronomiste voltooi. Hierdie weergawe (waarvan reste onder die Dooie See-rolle gevind is) is toe in Grieks vertaal in die tweede eeu. Die Griekse weergawe is egter ongeveer 'n agste korter as die Hebreeuse teks wat finaal in ongeveer $100 \mathrm{nC}$ aanvaar is en wat ten grondslag van ons Bybels vandag lê. Klaarblyklik het die literêre aktiwiteit aan die boek baie lank voortgeduur - 'n teken van die boek en sy boodskap se gewildheid en toepaslikheid in nuwe situasies.

12 Die huidige boek Jeremia bevat woorde van Jeremia sowel as van sy redigeerders. Veral hoofstukke 26-45 en 50-52 het betrekking op die ballingskap. Die volgende is van die prominentste gedeeltes wat aan JerD toegeskryf word en oor die hele boek strek (vgl R Smend, Die Entstehung des Alten Testaments, Stuttgart 21981 , 158-159): 1:1-4; 3:6-18; 7:1-8:3; 11:1-14; 12:14-17; 13:1-14; 14:11-16; 16:1-13; 17:19-27; 18:1-12; 19:1-13; 21:1-10; 22:1-5; 23:1-8; 24; $25: 1-29 ; 27 ; 29: 8-19 ; 30: 1-3 ; 31: 27-34 ; 32: 16-44 ; 34: 8-22 ; 35 ; 42: 10-22$; 44:1-14,20-23,27-30.

13 Indien Jeremia se hele loopbaan in oënskou geneem word, kan daar vier periodes onderskei word waartydens hy opgetree het: (1) 626-620: vanaf sy roeping tot en met die hervorming van Josia (hy spreek 'n oordeel uit oor Juda en bevraagteken sekere aspekte van Josia se hervorming). Hierna volg 'n periode van swye volg (620-609); (2) 609-597: tydens die regering van Jojagin (Jeremia voorspel die val van Jenusalem indien afgodediens en sosiale ongeregtigheid voorduur); (3) 597-580: tydens die regering van Sedekia en Gedalja (Jeremia verkondig onderwerping aan en samewerking met Babilonië as in belang van Juda); (4) 580 tot sy dood: in Egipte na gedwonge wegvoering (Jeremia verkondig dat Nebukadnesar Egipte - en die Judese vlugtelinge - sal onderwerp). 
14 Vir 'n bespreking van hierdie teks in historiese konteks vergelyk E H Scheffler, "A holistic historical background against which Jermiah 7:1-15 makes sense", OTE 7/3 (1994), 381-395.

15 Verse 1-9 van die boek Obadja handel oor die aankondiging van die vernietiging van Edom, verse 10-14 oor die redes vir die vernietiging, verse 15-21 oor straf vir die nasies en 17-21 oor die glorieryke herstel van Juda en Israel in die toekoms.

16 Die Deuteronomistiese redigeerders was verantwoordelik vir die finale samestelling van die werk as geheel. Volgens die meeste geleerdes kan hulle hand verder duidelik in die volgende verse gesien word: Deuteronomium 1$4: 40 ; 29: 1-29 ; 30: 1-20 ; 31: 1-29 ; 32: 44-47 ; 34: 1-12$; Josua $1: 3-9 ; 1: 12-18$; 8:30-35; 10:16-43; 11:10-20; 22:1-8; 23:1-16; 24; Rigters 2:6-3:6; 3:12-15,30; $4: 1-3,23-24 ; 5: 31 ; 6: 1,6 ; 8: 27-35 ; 10: 6-10 ; 11: 33 ; 13: 1 ; 15: 20 ; 1$ Samuel 2:22-36; 4:18; 7:1-17; 2 Samuel 5:4-5; 7; 1 Konings 8:46-53; 9:6-9; 2 Konings $17: 19 ; 20: 17-19 ; 21: 2-16 ; 23-25$.

17 'n Kort indeling van die inhoud van die boek Esegiël kan so lyk: Hoofstukke 13: Esegiël se roeping; 4-24: Oordeelsprofesie oor Jerusalem; 25-32: Oordeelsprofesieẽ oor die vreemde nasies; 33-39: Die bevryding, terugkeer en vereniging van Israel; 40-48: Esegiël se bloudruk: 'n nuwe tempel, kultus en land. Uiteraard het daar ook 'n latere redaksie(s) van die boek plaasgevind.

18 Vergelyk J H Le Roux, Revolution and reinterpretation, Kaapstad 1987, 135138.

19 Vergelyk Le Roux, $a w, 135-138$.

20 Die volgende word tradisioneel as die P-gedeeltes van die Pentateug beskou (vgl bv G Fohrer, Einleitung in das Alte Testament, Heidelberg $\left.{ }^{11} 1969,195-196\right)$ : Genesis 1:1-2:4a; 5; 6:9-8:22; 9:1-17; 17; 23; 25:12-20; 27:46-28:9; 35; Eksodus 6-7; 12:1-13-2; 24-25; 34:29-40; Levitikus 1-10; 10-15; 16; 17-26; 27; Numeri 1:1-1:10; 10:11-28; 13:1-14:45; 15; 16-17; 18-19; 26; 27; 28-30; 31 ; 33:1-49; 33:50-34:29; 35; 36; Deuteronomium 34:1.7-12. P kom ook in Josua voor, veral ten opsigte van die verdeling van die land: 13:1-33; 14:1-15; 15:1-63; 16:1-10; 17:1-18; 18:1-28; 19:1-9; 19:10-51.

21 Vergelyk J B Pritchard, Archaeology and the Old Testament, Princeton 1958, 192. Die verklaring van Genesis 1 se skeppingsverhaal in sy historiese konteks, te wete as ' $n$ reaksie op die Babiloniese verhaal maak religieuse dispute rondom ewolusie en die letterlike interpretasie van Genesis 1 oorbodig.

22 Vir die gepaste benaminge "Jesaja van Jerusalem" en "Jesaja van die ballingskap" vergelyk N Gottwald, The Hebrew Bible: a socio-literary introduction, Philadelphia 1985, 377 en 492.

23 Vergelyk E H Scheffler, "Dimensions of suffering in Deutero-Isaiah", in: W J Wessels \& E H Scheffler (eds), Old Testament science and reality: a mosaic for Deist, Pretoria 1992, 208-224.

$24 \quad$ Vir 'n inhoudsoorsig van Deutero-Jesaja, vergelyk Scheffler, $a w, 211$.

25 Vergelyk Scheffler, $a w, 220-221$.

26 Die vier knegliedere kom voor in Jes 42:1-9 (die empatie van die kneg); 49:1-7 (die kneg as lig van die nasies); 50:4-11 (die gehoorsaamheid van die kneg) en 52:13-53:12 (die lydende kneg).

27 Boekdele is al geskryf oor die identiteit van die kneg van Jesaja 53. Dit kan Cyrus wees, Israel of die profeet self. Die feit dat die teks nie duidelik sê wie 
die kneg is nie, het egter opsigself betekenis. Deurdat die teks wat dit betref oop is, kry die funksie van die kneg, as een wat deur sy eie lyding ander se lyding verlig, meer klem. Jesaja 53 is dus 'n uitnodiging aan alle mense wat ly om deur hulle eie lyding instrumente te word in die hand van God ten einde ander se lyding te verlig. Geen wonder dat in die Nuwe Testament Jesus Christus se dood ook in terme van Jesaja 53 geïnterpreteer is nie. Vergelyk Scheffler, $a w$, 218-219. 